\title{
一側性反復性馬杉腎炎の組織病理学的研究
}

\author{
大阪市立大学医学部泌尿器科学教室 \\ (主任: 前川正信教授)
大阪市立大学医学部病理学第一教室 努 本亮 二**
(主任:藤本輝夫教授)
}

\section{A HISTOPATHOLOGICAL STUDY ON UNILATERAL RECURRENT MASUGI NEPHRITIS}

\author{
Ryoji Yasumoto \\ Department of Urology, Osaka City University Medical School \\ (Director: Prof. Dr. M. Maekawa) \\ Department of Pathology, Osaka City University Medical School
}

(Director: Prof. Dr. T. Fujimoto)

A histopathological study on unilateral recurrent Masugi nephritis, induced by repeated intravenous injections of anti-rabbit kidney hen serum into rabbits in the beginning of the course of clamping of right renal arteries for 20 minutes at intervals of one month, is presented. The mode of development of renal lesions in the same individual animals for up to 199 experimental days was ascertained on the basis of the findings of biopsy materials surgically resected repeatedly as well as autopsy materials.

The results are as follows:

1) In the left kidney, a recurrent glomerulonephritis leading to granular atrophy of the kidney was induced by means of repeated injections of anti-rabbit kidney hen sera, whereas, in the right kidney, there developed a mild and focal glomerulonephritis and a tendency to compensatory hypertrophy only after second injection.

2) Recent and old proliferative glomerulonephritis, formation of recent and fibrous epithelial crescent, recent endothelial proliferation in the glomerular capillary loops having sclerosed basement membrane, recent endothelial proliferation in the periphferally arranged blood space of glomerular loops having fibrosis, crowding of previously proliferated cells towards axis of the loops, etc. were induced in the left kidneys after second injections. They were interpreted as histological manifestations of the recurrence of Masugi nephritis. Subendothelial cellular proliferation with fibrosis of glomerular loops comparable in its histogenesis to that of "circumferential mesangial interposition" was also encountered in the left kidney having second injection of anti-rabbit kidney hen serum.

3) In the urinary tubular tissues especially those of proximal convolution attached to destructed glomeruli, there appeared atrophy of epithelial cells, hyaline thickening of basement membrane, and edema and sclerosis of interstitial tissue. A double-contoured thickening, loosing and undulation of tubular basement membrane associated with ingrowth of fibroblast and collagen fibers into the intervening tissues between atrophic epithelial cells and basement membrane were noted.

4) Perinuclear vesicle formation of leiomyofibers of the media of arterioles in the proximity to severely injured or destructed glomeruli was not infrequentl! observed.

要旨：慢性系球体腎炎の病理過程の解析のため，抗ウサギ腎ニワトリ血清を成熟傩りサギの一側腎動脈の20分 間の結紮中に耳静脈内に注射するという Sarre-Wirtz の方法を，およと1䇢月の間隔で反復することにより一

* 大阪市立大学大学院医学研究科外科系専攻(泌尿 器科学) 課程修了 
側性反復性馬杉腎炎の作成を試みた。最長観察期間は発病後199日に抢よんだが，抗腎血清の反復注射によつ ても馬杉腎炎の一側性発生の傾向が失なわれないことを確か㧹た。患側腎の時間の経過に従ら縮小傾向に反 して, 対側腎には多少とも肥大するといら結果が得られた。経時的生検および剖検による検索では, 同一系球 体に括ける新旧の増生性系球体炎像や半月体形成拉よびその線維化ならびに基底膜の硬化・肥厚のみられる係 蹄に拈ける新しい細胞増生, 線維化に伴い増生細胞が中軸部に集積した保蹄の周辺側における胞体の明るい内 皮細胞由来と思われる細胞の出現が注目された。これらは抗腎血清注射の反復による糸球体炎の再発像と考元 られる。その他に，糸球体俰蹄の壞死後の肉芽腫形成像や倸蹄の周辺毛細血管壁に怙ける “Circumferential mesangial interposition” に相当する像も観察された。このような傷害の強い糸球体に所属する尿細管主部組 織には上皮の著明な萎縮, 基底膜の二重化・疎開・蛇行, 萎縮上皮と基底膜との間の線維芽細胞, 膠原線維の 出現，間質の硬化などが注目された。傷害の強い系球体に注ぐ細動脈の中膜平滑筇線維の周核空胞形成も観察 された。

\section{緒 言}

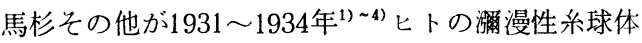
腎炎に匹敵する実験的系球体腎炎，いわゆる馬杉腎炎を 作成することに成功して以来, 系球体腎炎の研究が急速 に進展し，多大の成果がもたらされた．藤本 $(1954)^{5)}$, 藤本その他 $(1955,1964)^{6) ~ 8)}$ はウサギ怙よびダイコク ネズミに馬杉腎炎を作成し，経時的な腎生検によつて 同一動物に打ける系球体腎炎の進展様相を，はじめて動 的に追究した. Sarre \& Wirtz (1939) 9) はウサギの左腎 動脈を結禁するのと同時に抗ウサギ腎アヒル血清をとの 耳静脈内に注射し，15分後に再び結紮を解くことによ り，右腎のみに糸球体腎炎を作成することに成功した。 菅井 $(1957)^{10)}$ は Sarre-Wirtz の方法にしたがつて，抗 ウサギ腎アヒル血清注射後96日にわたる馬杉腎炎の一側 発生を両側腎生検の反復により確かめ, 椎名 $(1959)^{11)}$ は Sarre-Wirtz の方法の反復により，他側腎をほぼ正常 に保ちつつ, 一側性の亜急性系球体腎炎・続発性萎縮腎 を作成することができた。

このいわゆる一側性馬杉腎炎の実験方法を応用するこ とにより，動物の一側の腎機能をほぼ確実に保ちなが ら，他側の糸球体腎炎による徹底的な傷害を作成するこ とが可能と思われる.

このたび，著者はウサギの一側腎動脈の20分間の結紮 中に，抗ウサギ腎ニワトリ血清をその耳静脈内に注射す る方法を反復することによりウサギに一側性から反復性 の糸球体腎炎の作成を試みたが，その際発生を見た腎内 の病理過程について経時的な検索を行ない, 若干の成果 を得たのでここに報告する.

\section{実験材料および方法}

1. 抗ウサギ腎ニワトリ血清の作製

1）ウサギ腎皮質弹によるニワトリ感作：成熟ウサギ （雌，2.0〜3.8kg）を仰臥位に固定後，腹部を広範囲に 剃毛し，イソジン®で消毒し，その正中線で切開し腹腔 内容物を压排するとともに，腎動脈分枝部の上拈よび下 の位置で腹部大動脈と下大静脈に絹糸とかけ結皆し，そ れと同時にヘパリン 5000 単位加生理的食塩水容器を高さ 約 $1.5 \mathrm{~m}$ の位置においてこれにつらなつた $23 \mathrm{G}$ エラス ター針を結紮部の間の腹部大動脈内に挿入した後, 両側 腎静脈を切開開放し，両腎が全く血色を失うまで潅流し た. 全く血色が消失した両側腎より皮質部分を切除し， Potter's homogenizer ですりつぶし，10\%エマルジョン になるよう生理的食塩水を加光た. Freund incomplete adjuvant (Difco 社製) と10\%エマルジョンとの比が 1：1になるように充分混和して, 総計 18 羽のニワトリ (バブュック B-300, 雌, $1.8 \sim 2.2 \mathrm{~kg}$ ) の両下肢に $4 \mathrm{ml}$ ずつ, 週 1 回の割りで筋肉注射し計12週間感作した.

2）抗ウサギ腎ニワトリ血清の採血和よび沈降抗体価 の測定 : 採血は感作終了後 1 週間目に, 両側翼下静脈上 り行なつた. 採血は 1 羽あたり $30 \sim 50 \mathrm{ml}$ 可能で, 得ら れた血液を直ちに遠心分離して血清を得, それぞれの= ワトリのものを混合して $-20^{\circ} \mathrm{C}$ 下に使用時まで保存し た. 一連の実験にはすべて同一の保存血清を使用した.

この保存血清の沈降抗体価測定は, 既述の10\%ウサギ 腎皮質弹を抗原として用い, カウンター電気泳動法で行 なつた．実験に使用した保存血清の沈降抗体価は，126 号血清で250倍, 209号血清で350倍, 541号血清で270倍 であつた.

2.一側腎動脈結禁ウサギに扣ける抗ウサギ腎ニワト リ血清の静注

尿検査上異常所見の認められない雌ウサギ11匹（体重 $1.35 \sim 3.8 \mathrm{~kg}$ ）を用いた。.ウサギを腹臥位または側臥位 に固定し，腰背部の 皮霄を広範囲に消毒したのち切開 
し，その切開創の間から腹膜を損傷することなく腎を創 外に脱転し，腎門部の腎動脈にゴム付鈤子をかけた。そ れと同時に耳静脈より体重 $\mathrm{kg}$ あたり $2.5 \mathrm{ml}$ の抗ウサ ギ腎ニワトリ血清を静注した。 2 回目の静注にあたつて は，アナフィラキシーショック䂆防のため，その約 30 分 前に $2 \mathrm{ml}$ の抗腎血清を筋注し, その後異常所見のあら われないことを確認してから抗腎血清の静注を行なつ た. 腎動脈の結柇時間は20分間で, 結紮を解いてから腎 表面の色調が元にもどるのを確認したのち，カットガッ 卜を用いて切開創を縫合した。な特，縫合後感染予防の ため，セファゾリン $0.5 \mathrm{~g}$ を筋注した。

3. 臨床検査 (尿検查など)

抗腎血清静注後 1 週間は，連日 3 号 Nélatonを用い て膀胼尿を採取して尿検查を行ない，その後は $1 \sim 2$ 週 毎に同様の方法で，採取した尿について検査を繰り返し た.

体重測定は $1 \sim 2$ 週毎に行ない，全身状態の指標とし た.

\section{4. 腎の部分切除（生倹）}

抗腎血清を注射したウサギについて，蛋白尿が出現し た日より，藤本の方法 ${ }^{5)}$ 飞従つて $1 \sim 3$ 回患側腎の小組 織片の楔状切除を行ない病理組織学的検索に資した。対 側腎については，少数の動物に括いて腎動脈結紮を解い てから10分後および抗腎血清の 初回注射後 1 週間を経 て，同様の方法で腎生検を行なつた。部分的切除にあた つては，第 1 回切除をなるべく腎上極に近い部分で行な い，回を重ねるにしたがつて下方に及ぶのを常とした。 この方法は前回の切除による周囲組織と腎との癒着にも とづく切除の困難さを軽減させるのに役立つた.

\section{5 . 剖検}

尖験ウサギを监白尿出現後 2-199日にて剖検した。 腎については，その重量，大きさ（長径 $\times$ 短径 $\times$ 厚さ）, 表面の性状，線維膜の䟝離の難易，皮質の厚さなどを観 察ならびに計測した。

\section{6. 組織学的検索}

1) 光学顕微鏡 (以下光顕之略す) 的娭䋕

腎の部分切除の材料ならびに剖検時の腎を $10 \%$ フル マリン水で固定した．パラフィン包埋薄切切片について は，へマトキシリン・エオジン染色 (HE 染色)，過沃 素酸シッフ染色 (PAS 染色) を行なつて観察し, 適宜, 他の染色法をも加觉た。

2) 蛍光抗体法

腎の部分的切除材料は, Tissue-Tek $11{ }^{\circledR}$ (Lab-Tek products 製）にて包埋した後, Cryostat II にて厚さ $6 \mu$ の切片を作製した. 95\% ethyl alcohol で固定後, 燐酸 buffer で洗浄し， 5 倍希䣋 の FITC 抗ウサギ $\gamma$ グロブ リンヤギ血清 ${ }^{\circledR}$ (Hoechst 製) を用いて，直接法で検索 した. 観察及び 撮影には Carl-Zeiss 社製蛍光顕微鏡を 用いた。

3）電子顕微鏡（以下電顕と略す）的検索

腎の部分切除材料および剖検材料については，採取後 ただちに $0.2 \mathrm{M}$ 燐酸緩衝液（pH 7.4）で希釈した $6 \%$ グルタールアルデヒドの中で約 $1 \mathrm{~mm}^{3}$ の大きさに細切 し， $4{ }^{\circ} \mathrm{C}$ 条件下で 2 時間の前固定を行なつた. 次に, $4{ }^{\circ} \mathrm{C}$ 条件下で $1 \% \mathrm{OsO}_{4}$ を含む燐酸緩衝液の中で約 2 時間, 後固定した. 一部の切除材料については, $4{ }^{\circ} \mathrm{C}$ の条件下で， $2 \%$ コリジ緩衝液 $(\mathrm{pH} 7.4)$ で希釈し た $1 \%$ オスミウム酸で 2 時間の前固定を, 次に $6 \%$ グル タールアルデヒド中で約 2 時間の後固定を行なつた. そ の後, 常温下にてェタノール系列で脱水後, Epon 812 (Luft 法) にて包埋し $60^{\circ} \mathrm{C}$ 保温器 の中に数日間放置 した. 次に, Porter-Blum MT II B のウルトラミクロ トームで超薄切片を作成し，酢酸ウラニウム（Watson 変法）括よびクエン酸鉛（Reynold 法）の二重染色を行 ない，日立 HS-9型電子顕微鏡を用いて，観察特よび撮 影を行なつた。な拉，超薄切片作成前に約 $500 \mathrm{~m} \mu$ 厚の 切片を作成して，トルイジン青染色を施し，光顕的検索 の後，エポン包埋材料を超薄切片用にトリミングした.

\section{実験成績}

\section{1. 蹊床所見}

表 1 は著者の笑験成績を一括したものである．観察期 間は7 日間から204日にわたり，蛋白尿出現は初回抗腎 血清注射後 $5 \sim 7$ 日で認められ，多くの動物ではその後 蛋白尿の程度は減じて行き，17〜24日で消失した。 しか し，ウサギ No. 5，6，9，10では程度の差は岁つたが蛋 白尿は消失することはなかつた．第 2 回の抗腎血清注射 後，3〜8日を経て蛋白尿は再度出現あるいは増強を示 し，その後剖検時まで持続していた。尿沈渣所見では， 蛋白尿の程度に応じて, 赤血球, 白血球, 円柱ならびに 上皮の増加が観察された。

2. 病理学的所見

A. 腎の肉眼的所見

腎線維膜の䟝離は腎の部分切除にともなう喻着の部分 を除き，全例に打いて容易であり，腎表面は大部分平滑 であつたが，細顆粒状を呈する動物も一部に認められ た。腎実質内には生検による血腫ないし洀痕が一部に認 
表 1 実験成績の概要

\begin{tabular}{|c|c|c|c|c|c|c|c|c|c|c|c|}
\hline \multirow{2}{*}{$\begin{array}{l}\text { ウ } \\
\text { サ } \\
\text { ギ } \\
\text { No. }\end{array}$} & \multirow{2}{*}{$\begin{array}{l}\text { 体重 } \\
\text { (g) } \\
\text { (初 } \\
\text { 終 }\end{array}$} & \multirow{2}{*}{$\begin{array}{c}\text { 抗孯血清の注射 } \\
\text { 抗督血清 } \\
\text { (月日) }\end{array}$} & \multirow{2}{*}{$\begin{array}{l}\text { 初回注 } \\
\text { 射後の } \\
\text { 蛋沓 } \\
\text { 出 現 } \\
\text { (月旦) }\end{array}$} & \multirow{2}{*}{ 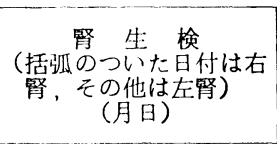 } & \multirow[t]{2}{*}{ (剖検 } & \multicolumn{2}{|c|}{$\begin{array}{l}\text { 剖検時の } \\
\text { 繁 } \\
(\mathrm{g})\end{array}$} & \multicolumn{2}{|c|}{$\begin{array}{c}\text { 剖検時の腎の大きさ } \\
(\mathrm{mm})\end{array}$} & \multicolumn{2}{|c|}{$\begin{array}{c}\text { 皮質の厚さ } \\
(\mathrm{mm})\end{array}$} \\
\hline & & & & & & 左 & 右 & 左 & 右 & 左 & 右 \\
\hline 1 & $\begin{array}{l}1700 \\
1650\end{array}$ & $\begin{array}{c}126 \text { 号 } \\
(17 / \text { II })\end{array}$ & $22 /$ II & $24 /$ II & $24 /$ II & 9.8 & 9.0 & $37 \times 25 \times 20$ & $36 \times 25 \times 20$ & 3.0 & 2.9 \\
\hline 4 & $\begin{array}{l}2250 \\
2000\end{array}$ & $\begin{array}{c}209 \text { 号 } \\
(17 / \text { II })\end{array}$ & $22 /$ II & $24 /$ II & $2 /$ III & 8.5 & 10.6 & $31 \times 30 \times 17$ & $34 \times 24 \times 19$ & 2.3 & 2.9 \\
\hline 7 & $\begin{array}{l}1600 \\
1500\end{array}$ & $\begin{array}{c}126 \text { 号 } \\
(18 / \text { II })\end{array}$ & $25 /$ II & $24 /$ II & $4 /$ III & 9.4 & 9.2 & $32 \times 17 \times 16$ & $28 \times 18 \times 16$ & 2.9 & 2.9 \\
\hline 2 & $\begin{array}{r}1350 \\
750 \\
\end{array}$ & $\begin{array}{l}1126 \text { 号 } \\
(4 / \text { II })\end{array}$ & $10 /$ II & & $23 /$ II & 4.7 & 4.9 & $25 \times 16 \times 14$ & $27 \times 22 \times 13$ & 2.5 & 2.7 \\
\hline 6 & $\begin{array}{l}3400 \\
1950 \\
\end{array}$ & $\begin{array}{c}126 \text { 号 } \\
(18 / \text { II }) \\
\end{array}$ & $24 /$ II & $(18 /$ II $), \quad 29 /$ II & $14 / \mathrm{IV}$ & 8.0 & 8.9 & $36 \times 17 \times 16$ & $36 \times 21 \times 16$ & 3.3 & 3.7 \\
\hline 10 & $\begin{array}{l}2100 \\
1700 \\
\end{array}$ & $\begin{array}{c}209 \text { 号 } 209 \text { 号 } \\
(7 / \mathrm{IV})(12 / \mathrm{V})\end{array}$ & $12 / \mathrm{IV}$ & $28 / \mathrm{IV},(28 / \mathrm{IV}), 26 / \mathrm{V}$ & $9 / \mathrm{MII}$ & 7.4 & 9.2 & $32 \times 22 \times 14$ & $34 \times 24 \times 17$ & 3.5 & 3.6 \\
\hline 8 & $\begin{array}{l}3850 \\
3100\end{array}$ & $\begin{array}{c}126 \text { 号 } \\
(6 / \text { III })\end{array}$ & $11 /$ III & $14 /$ III & $26 /$ III & 7.6 & 11.7 & $36 \times 20 \times 17$ & $37 \times 22 \times 19$ & 2.8 & 3.3 \\
\hline 11 & $\begin{array}{l}1600 \\
1630 \\
\end{array}$ & $\left(\begin{array}{c}541 \text { 号 } \\
(7 / \mathrm{V})\end{array}\right.$ & $12 / \mathrm{IV}$ & $15 / \mathrm{IV}$ & $18 / \mathrm{IV}$ & 8.8 & 9.8 & $34 \times 24 \times 14$ & $35 \times 22 \times 18$ & 3.0 & 3.2 \\
\hline 3 & $\begin{array}{l}1800 \\
2150 \\
\end{array}$ & $\begin{array}{c}126 \text { 号 } 126 \text { 号 } \\
(3 / \text { II })(28 / \text { II })\end{array}$ & $8 /$ II & $28 /$ II & $4 /$ III & 7.5 & 14.0 & $31 \times 22 \times 20$ & $41 \times 31 \times 22$ & 3.2 & 3.2 \\
\hline 5 & $\begin{array}{l}3600 \\
3500 \\
\end{array}$ & $\begin{array}{c}209 \text { 号 } 209 \text { 号 } \\
(17 / \text { II })(18 / \text { III })\end{array}$ & $22 /$ II & $(20 /$ II $), 27 /$ II, $23 /$ III & $18 / \mathrm{IV}$ & 15.7 & 19.0 & $37 \times 34 \times 22$ & $42 \times 37 \times 22$ & 3.0 & 3.5 \\
\hline 9 & $\begin{array}{l}2050 \\
2020 \\
\end{array}$ & $\begin{array}{c}126 \text { 号 } 126 \text { 号 } \\
(6 / \text { III })(31 / \text { III })\end{array}$ & $11 /$ III & $31 /$ III $, 7 / \mathrm{V}, 5 / \mathrm{VI}$ & $25 / \mathrm{IX}$ & 5.0 & 18.0 & $28 \times 20 \times 17$ & $55 \times 35 \times 23$ & 1.5 & 3.6 \\
\hline
\end{tabular}

実験期間：17/II，1978 25/IX，1978

表 2 腎蔵所見り概要

\begin{tabular}{|c|c|c|c|c|}
\hline ウ & 左 & 腎 & & \\
\hline $\begin{array}{l}f * \\
\text { No. }\end{array}$ & 系 球 体 & 尿細管組織 & $\begin{array}{l}\text { 細動脈 (中膜 } \\
\text { 平滑筋線維) }\end{array}$ & 右 \\
\hline 1 & $\begin{array}{l}\text { 係蹄壁の浮腫性胿化 } \\
\text { 細胞增生 (一部) } \\
\end{array}$ & $\begin{array}{l}\text { 上皮菲薄化 } \\
\text { 厑賏浮腫 }\end{array}$ & $(-)$ & $(-)$ \\
\hline 4 & 係蹄壁の浮腫性膨化 & 間質浮腫（軽度） & $(-)$ & $(-)$ \\
\hline 7 & 係蹄壁の浮腫性膨化 & 間質浮腫（軽度） & $(-)$ & $(-) \rightarrow(-)$ \\
\hline 2 & $\begin{array}{l}\text { 係蹄壁の浮腫性膨化 } \\
\text { 細胞增生 }\end{array}$ & $\begin{array}{l}\text { 間質浮腫 } \\
\text { 円柱, 硝子滴変性 }\end{array}$ & $(-)$ & $(-)$ \\
\hline 6 & $\begin{array}{l}\text { 係蹄中軸部浮腫 } \rightarrow \text { 中軸部硬化 } \\
\text { 新しい細胞增生，半月体形成 }\end{array}$ & $\begin{array}{l}\text { 上皮菲薄化 } \\
\text { 僴質硬化 }\end{array}$ & $(-)$ & $(-) \rightarrow(-)$ \\
\hline 10 & $\begin{array}{l}\text { 中軸部への増生細胞の集皘 } \\
\text { 基底膜の硬化のある係蹄の細胞増生 }\end{array}$ & 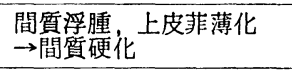 & $\begin{array}{l}\text { 核周囲 } \\
\text { 淡明化 }\end{array}$ & $\rightarrow$ 巣状系球体腎炎 (一部) \\
\hline 8 & $\begin{array}{l}\text { 係蹄壁の浮腫性胿华 } \\
\text { 中軸部への増生細胞の集積 }\end{array}$ & 間質浮腫（軽度） & $(-)$ & $(-)$ \\
\hline 11 & 係蹄中軸部細胞増生 & 間質浮腫（軽度） & $(-)$ & $(-)$ \\
\hline 3 & $\begin{array}{l}\text { 係蹄壁の浮腫性膨化 } \\
\rightarrow \text { 中軸部浮腫性膨化, 細生 }\end{array}$ & $\begin{array}{l}\text { 間質浮腫，上皮菲薄化 } \\
\rightarrow \text { 上皮の萎縮，間筫化 }\end{array}$ & $(-)$ & 巣状系球体腎炎 (一部) \\
\hline 5 & $\begin{array}{l}\text { 係蹄中軸部浮腫性膨化, 細胞増生 } \\
\rightarrow \text { 半月体, 众芽膨形成 }\end{array}$ & $\begin{array}{l}\text { 間質浮腫,芒皮菲薄化 } \\
\rightarrow \text { 上縮, 間質化 }\end{array}$ & $\begin{array}{l}\text { 核周囲 } \\
\text { 淡明化 } \\
\end{array}$ & $\rightarrow$ 巣状系球体腎炎 (一部) \\
\hline 9 & 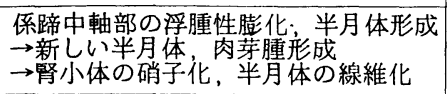 & $\begin{array}{l}\text { 間質浮腫萎縮, 皮菲薄貨硬化 } \\
\rightarrow \text { 上皮 }\end{array}$ & $\begin{array}{l}\text { 核周囲 } \\
\text { 淡明化 }\end{array}$ & $\begin{array}{l}\text { 笨状系球体腎炎(軽度) } \\
\text { 代侻性肥大 }\end{array}$ \\
\hline
\end{tabular}


められたが，他の実質には巣状病変は認められなから た. 腎荋粘膜の肥厚, 点状出血などは認められず，大部 分の動物では腎孟・尿管内に微細な尿砂が観察され，一 例に結石様物質がみられた。 また，一例に尿路拡張提* が既に発生していたことが明らかにされたが，水腎症的 な㹂障害像は認められなかつた，弓状動脈の位置を基準 にして皮質の厚さを測定すると表に示すように, 患側婜 の方でそれが有意に減少しているのが観察された。

B. 䖢光抗体法の所見

䖺光抗体直接法に上る検索（抗腎血清静注後 7 日， 24 日）によると, ウサギ $\gamma$ グロブリンはこのいずれの実験 日に扣いても系球体係蹄基底膜に沿つて線状にその局在 が示されたが，尿細管上皮下基底膜にはその沈着はみら れなかつた。

C. 病理組織学的所見

恼理組織学的所見の概要は表 2 亿示すごとくである. その中で, 臨床的ならびに病理形態学的な経過観察が比 較的良く行なわれた動物数例について記載することにす る.

（1），サギ No. 1 (126号血清)

\section{a. 尿所見}

抗腎血清静注後 5 日より蛋白尿が出見し, 2 日後の剖 検時まで続いた。尿沈椬には剝離上皮や円柱も認められ た.

\section{b. 蛋白尿出現後 2 日（剖検）}

右腎：肉眼的にも組織学的にも異常所見は見い出され なかつた（重量 $9.0 \mathrm{~g}$ ).

左腎：重量は $9.8 \mathrm{~g}$ で，右腎に比してやや腫大してお り暗赤色を呈していた，線維膜の剥離は容易で，表面は 平滑, 割面でも異常は認められなかつた。

組織学的には，著明な変化が糸球体ならびに尿細管組 織**に認められる。すなわち，系球体は腫大し，系球体 係蹄基底膜は溸漫性に肥厚し，エオジンで均質に染まつ ている. また，一部には係蹄局所の固着細胞（主として 内皮細胞由来）の増生が認められ，増生細胞が細網状配 列を示寸像も見られる。ボウマン囊腔は狭くなつてい る. 尿細管主部の上皮細胞は菲薄化し，管腔が拡張して いる様にみえるが，電䫓による検索では細胞の微細構造 ならびに基底膜に著しい変化が認められない，尿細管組

* 脚注 : 藤本輝夫, 他の記載（札幌医誌31，224一 235,1967) に従った。

** 脚注: 岡林篤, 藤本輝夫の記載 (最新医学 14 , 1741ー1750，1959）に従った。
織の間質には，軽度のリンパ球の浸潤ならびに毛細血管 腔内の血浆停滞が認められる.

（2）ウサギ No. 5 (209号血清)

\section{a. 尿所見}

抗腎血清静注後 5 日に蛋白尿が出現し，しだいに増強 を示し，第 2 回抗腎血清注射後（第 1 回上り 30 日）約 7 日間は蛋白尿が著明に増加し, その後多少軽減した状態 で剖検を行なつた55日目まで持続していた，尿沈椬では 赤血球，白血球，円柱，上皮等が蛋白尿増強と核湾時を 同じくして認められた。

b. 蛋白尿出現後 5 日（第 1 回生検）

左腎はやや腫大気味で，暗赤色を呈していた．切除部 の線維膜の剥離は容易で，表面は平滑であつた．組織学 的にはほとんどすべての糸球体に炎症性変化が認められ る. 系球体は一般に腫大し, 細胞に富み, 貧血性であ る. 系球体係蹄についてみると, 基底膜の䨕漫性肥厚, 偽好酸球の毛細血管内集積, 類線維素血栓の形成ならび に係蹄中軸部の浮腫, 係蹄局所に打ける主に内皮細胞に 由来する細胞の増生による細網状構造が観察される。 た，ボウマン霊腔中への血浆成分の漏出ならびに出血を 認める. 周囲の間質は浮腫を示し, 電顕的検索では一部 に線維芽細胞も認められ，さらに一部のボウマン囊周囲 組織にリンパ球様細胞の浸潤が認められる.

c. 蛋白尿出現後25日（第 2 回生検）

第 1 回生検時の手術瘢痕創以外には, 肉眼的に異常を 認めなからた。

組織学的観察では, 標本中の約半数の糸球体では係蹿 構造が比較的よく保たれているが，系球体係蹄基底膜の 二重に見方る像や系球体係蹄とボウマン囊壁との癒着, さらに半月体形成が観察される. そして，そのよらなボ ウマン咳の周囲組織には線維成分の増殖と浮腫が認めら れ，リンパ球，形質細胞や偽好酸球等の浸潤も観察され る. 一方, 残りの約半数の糸球体では, 係蹄に増生した 細胞に沿つて線維化（電顕的には係蹄基底膜につらなる 基底膜様構造の形成や膠原線維 の增殖）が進行した結 果, これらの細胞が係蹄中軸部に集積し, 係蹄周辺部に 血腔が不規則に並んで形成されているところや，倸蹿の 毛細血管構造に著しい変化がなく, 係蹄中軸部 (メサン ギウム領域）に礎質 (mesangial matrix) の增加や細線 維の多少の増殖がみられる部分もあり, 複雑に蛇行し入 り組んだ基底膜様構造の間に礎質の増加扣よび膠原線維 の増殖が電顕的観察にて認められる.ささらに，係蹄毛細 血管の血栓形成ないし血行静止に伴つて壊死化した係蹄 
（図 1）に向かつてボウマン製壁から肉芽組織が侵入し つつある像が観察される（図 2 ）．硝子化を示す糸球体 はみられなかつた。

尿細管組織についてみると，尿細管主部上皮細胞は菲 薄化し, 電顕的に mitochondria の減少, lysosome の増 加が細胞質内に観察され，上皮下基底膜との間に線維成 分の存在が観察される．また，尿細管上皮下基底膜は二 重に見觉る像や疎開，蛇行を示すのが認められる．これ らの变化は，電顕的に容易に確認される．その周辺の間 質には lysosome や phagolysosome を胞体内にもつ大 食細胞，粗面小胞体が層状に発達した形質細胞，単球な どの細胞浸潤と線維成分の増殖が認められる．周囲の毛 細血管腔は一般によく開存していて，そこには赤血球も 観察されるが，一部に血浆停滞が恋められるものもあ る.

d. 蛋白尿出現後55日一第 2 回抗 腎 血清 注 射後34日 (剖検)

右腎：肉眼的には異常を認めない（重量 $19.0 \mathrm{~g}$ )。組織 学的には軽度の巣状系球体腎炎像が認められる以外に, 大部分の糸球体や尿細管組織には異常所見は見当たらな かつた.

左腎 : 生検のための痗痕の部を除いては線維膜の剝離 は容易で，表面はおおむね平滑であるが，一部紐顆粒状 を呈していた（重量 $15.7 \mathrm{~g}$ ). 顕微鏡的には大部分の糸球 体に病的变化が観察される.すなわち，系球体係蹄の基 底膜の蛇行ないし不整な走行, 系球体係蹄中軸部の線維 化を伴つた増生した細胞の集積（図 3 ），係蹄中軸部の 線維化や硬化ならびに系球体全体が肉芽腫に置換されて いる像が観察される．係蹄中軸部の増生細胞の集積部を 電顕にて観察すると，胞体内に mitochondria p粗面小 胞体を認める線維芽細胞様の特徵を有寸細胞やそれらの 細胞間の膠原線維などが認められる（図 9)。また，不 整を示す係蹄基底膜間に増生細胞が位置し, “Circumferential mesangial interposition” に似て見觉るところる ある（図 4)。また，一部の糸球体に接して，線維化あ るいは硝子化㴼つた半月体も認められる.

尿細管組織では，とくに主部上皮の著しい萎縮と間質 の硬化像が注目され，このような尿細管の内腔には蛋白 円柱がところどころに観察される，尿細管上皮下基底膜 は二重, 蹯開, 蛇行, 肥厚などを示し, その変化がヘン レの係嵭にまで波及しているところもある．尿細管主部 上皮と上皮下基底膜との間には線維成分（膠原線維）の 增殖や線維芽細胞の增生が観察されるところがあり，こ
のような組織像は電顕的検索でも明瞭に認められる，細 動脈の中膜の平滑筋線維の核周囲の淡明化が認められ る.

（3）ウサギ No. 6 (126号血清)

a. 尿所見

抗腎血清静注後 6 日より蛋白尿が出現し, 剖検時まで 持続していた，尿沈渣では赤血球，槑離上皮，円柱が観 察された。

b. 蛋白尿出現後 5 日 (生検)

左腎は肉眼的に軽度に腫大していた，組織学的には， 係蹄壁の浮腫や係蹄毛細血管の血栓形成，ボウマン襄と の瘑着なども観察され，一部係蹄中軸部の浮腫や主に内 皮に由来する細胞の増生による細網状構造がみられる. また，一部には血行静止による係蹄壊死やボウマン賈壁 との瘺着が観察される，尿細管組織についてみると，尿 細管主部上皮の菲薄化と, 拡張した内腔に蛋白性液が停 滞している所見が認められ，尿細管主部には軽度の硝子 滴変性が観察される．光顕的にも電顕的にも，尿細管上 皮下基底膜には著しい変化が認められない。

c. 蛋白尿出現後51日（剖検）

右腎：肉眼的に異常を認めなかつた。組織学的には, 多くの糸球体は係蹄毛細血管の内腔が比較的良く保たれ ているが，糸球体の一部の係蹄中軸部には多少の細胞増 加が認められるものもある. 尿細管組織には異常所見は 殆ど認められない（重量8.9g).

左腎：肉眼的には線維膜の肥厚が観察されるが，生検 による症痕の部以外では剝離は容易で，その実質表面は 平滑であつた。組織学的には, 糸球体の中軸部に線維成 分の増殖と増生細胞の集積ならびにボウマン嚢壁と糸球 体係蹄との癒着が認められる。電䫓では, 粗剛なクロマ チンを有する核をもつた暗い細胞と胞体の明るい細胞が 複雑に入り組んで，細胞間に多くの膠原線維が観察され る. 他の糸球体の一部には半月体形成なども観察され る.また，糸球体係蹄の毛細血管腔がよく開存している 部分も認められるが，その係蹄基底膜は不整な走向を示 したり，軽微ながら肥厚・二重像を呈している．電顕的 観察で系球体係蹄の内皮と lamina dense との間に，固 着細胞の増生抢よび lamina dense と連らなる基底膜様 構造や膠原線維の形成が認められるところがある.

尿細管主部上皮は菲薄化し, 内腔のやや拡張したもの も観察されるが，さらに萎縮が著しく内腔のほとんど認 められないものもある。このような主部上皮の微細構造 上の特色として，細胞内小器官とくに mitochondria の 
減少，基底部細胞膜嵌入の消失があげられる．尿細管上 皮下基底膜は肥厚・蛇行の像を示し，尿細管上皮との間 に線維成分（膠原線維）が認められる. 周囲の間質に は, 軽度の翏原線維の増殖や線維芽細胞の増生が認めら れる. 細動脈中膜平滑笳線維の核周囲の淡明化もところ どころに散見される（重量 $8.0 \mathrm{~g}$ ).

（4）ウサギ No. 10 (209号血清)

a. 尿所見, 抗腎血清静注後 5 日上り蛋白尿が出现し, その後程度の差はみられたが 中等度のまま持続してい た. 第 2 回抗腎血清注射（第 1 回抗腎血清注射後31日） 後, 蛋白尿は再び増加し, 多少とも軽減したが剖検時ま で持続していた，尿沈渣では，蛋白尿の增弶侍に赤血 球, 円柱等が観察された。

\section{b. 蛋白尿出現後17日（第 1 回生検）}

左腎：腎はほぼ正常大を示したが，組織学的には，内 皮細胞に由来すると思われる細胞増生，係蹄壁の浮腫な らびに係蹄毛細血管の血行静止像が観察される．尿細管 組織についてみると尿細管主部上皮の菲薄化とその拡張 した内腔に蛋白性液が停滞しているのが認められる。ま た，主部上皮の性状が拈扮むね保たれている所では硝子 滴変性も観察される. 光顕ならびに電顕的検索でも，尿 細管主部上皮下基底膜に疎鬆・肥厚などの変化を認め得 ない.

c. 蛋白尿出現後 45 日一第 2 回抗腎 血清注 射後13日 (第 2 回生検)

左腎 : 肉眼的には, 以前の生検部の線維膜の肥厚が観 察されるが，剩離はほぼ容易であつた．組織学的には， 糸球体の中軸部に細胞が集積し, 膠原線維の増殖も認め られ，その周辺側の血腔に新しく細胞が增生しているの

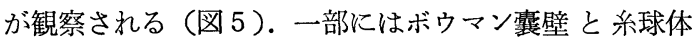
係蹄との癒着も認められる. 電顕的検索では, 系球体係 蹄中軸部には, 粗剛なクロマチンをもつ核のみられる暗 い細胞と胞体の明るい細胞が混在し，それら細胞間に多 数の膠原線維が観察される. また，このような係蹄の毛 細血管腔に胞体の明るい細胞が増生し，その細胞間に基 底膜構造 も認められる。一部には係蹄毛細血管内皮と lamina densa との閒にメザンギウム細胞に類似した暗 い細胞質をもつ細胞の増生ならびに膠原線維の増殖が観 察されるところもある。

尿細管主部上皮は萎縮して括り, 間質には線維芽細胞 の増生や膠原線維の增殖が著明である. 蹯鬆・疎開掞よ び肥厚を示す尿細管上皮下基底膜も認められる.

d. 蛋白尿出現後 120 日一第 2 回抗腎血 清注 身後 86 日
(剖検)

右腎：肉眼的にはその表面はほぼ平滑で，割面でも特 に異常を認めなかつた（重量 $9.2 \mathrm{~g}$ ). 組織学的には一部 に巣状系球体腎炎像が観察される以外には，大部分の系 球体や尿細管組織には異常所見はみられない。

左腎：肉眼的に線維膜は肥厚し，その䟝離は拈拈む权 容易であつた。腎実質の表面は注ぼ平滑を示し，重量は $7.4 \mathrm{~g}$ であつた. 組織学的には線維形成の久られる系球 体係蹄中軸部への増生細胞の集積, 硬化を示す系球休係 蹄基底膜の内腔側での細胞増生ならびに肉芽腫様变化に 陥つた系球体が観察される，また，係蹄とボウマン囊壁 との癒着や半月体形成を示す糸球体も散見される. 電㩆 的検索にて, 係蹄中軸部の増生した細胞間抢よびその周 囲に膠原線維の増殖ならびに基底膜様構造の形成が認め られ，その周囲の毛細血管腔内には主に胞体の明るく絊 胞内小器官の少ない内皮由来と考兄られる細胞の増生が 観察されるところもある.これらの増生細胞は不整・肥 厚を示す基底膜の血腔側を被覆している（図10).また， 一部の係踣周囲の毛細血管についてみると，係蹄毛細血 管内皮と lamina densa との間にメザンギウム細胞由来 と思われる細胞の増生を認め, さらに基底膜様構造・膠 原線維の形成も認められる.

尿細管組織についてみると，尿細管主部上皮の著明な 萎縮と間質の硬化が観察される. 電顕的には, mitochondria の減少, lysosome の增加ならびに基底部細胞膜 嵌入の消失が示される尿細管主部上皮と肥厚・蛇行を示 す尿細管上皮下基底膜との間に膠原線維の增殖や線維芽 細胞の出現が認められる．また，細動脈中膜平滑筋線維 の核周囲の淡明化もところどころに認められる。

（5）ウサギ No. 9 (126号血清)

a. 尿所見

経過図に示すように，第 1 回抗腎血清静注後 5 日より 蛋白尿が出現し, 第 2 回抗腎血清注射（第 1 回抗腎血清 注射後25日）後, 蛋白尿は著明に増加し，一過性に尿糖 も陽性を示した。な抢，蛋白尿はその後多少軽減した が，剖検時まで持続していた，尿沈椬では，赤血球，剝 離上皮，円柱などが蛋白尿増強時とほぼ時期を同じくし て観察された。

b. 蛋白尿出現後 20 日（第 1 回生検）

左腎: 腎の萎縮が軽度に認められたが，線維膜の肥厚 は認められず，その豩離も容易であつた．組織学的に は，大部分の系球体に炎症所見が観察され，係蹄局所に 和ける方として内皮に由来する固着細胞の增生に上る細 
経過図ウサギNo. 9 の経過

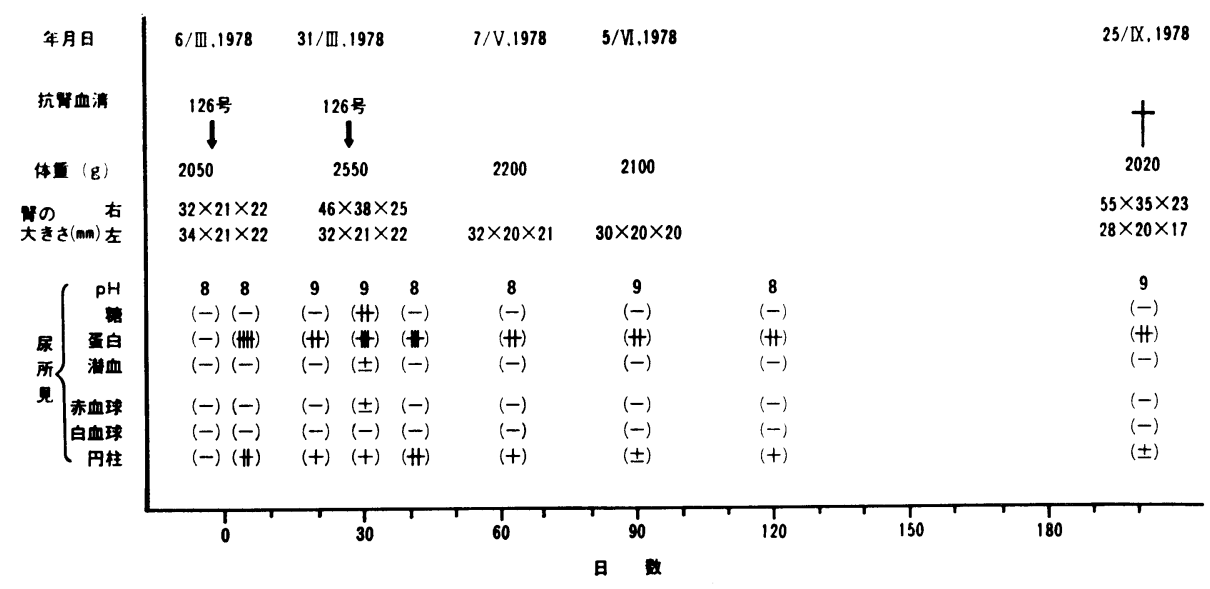

網状構造の形成，係蹄中軸部の浮腫や軽度の線維成分の 増殖，係蹄中軸部への増生した固着細胞の集積，一部系 球体係蹄壁の二重像や硬化が観察され，糸球体に接して 半月体形成が涩められるところもある. また，約半数の ボウマン輍の周囲に, リンパ球, 形質細胞, 単球などの 細胞浸潤や線維芽細胞・線維細胞の増生がみられる．係 蹄の電顕的観察では，内皮細胞やメザンギウム細胞の増 生, 中軸部に打ける mesangial matrix の増加と膠原線 維の増殖が認められる. 電顕的観察によると尿細管上皮 下基底膜の疎開，肥厚，蛇行の像が示され，それと主部 上皮との間に膠原線維の増殖が認められる.ささらに，そ の周囲の間質は一般に浮腫性で, そこに出血ならびにリ ンパ球, 形質細胞, 単球, 大食細胞などの増生・浸潤と 膠原線維の増殖がみられる。このよらな部の尿細管主部 上皮は, mitochondria の減少, lysosome の増加を示す.

c. 蛋白尿出現後58日一第 2 回抗腎 血清注 射後38日 (第 2 回生検)

左腎：肉眼的には線維膜の肥厚抢よび前回の切除に伴 う痗痕巣が認められるが，その他の部分では線維膜の剥 離は容易で, 腎表面は平滑であつた. 組織学的には, 系 球体係蹄の全体に拈よぶ細胞増生後の線維化（図 6) p 係蹄が肉芽腫に置換されつつある像が認められ，これら に所属する尿細管組織には主部上皮の著明な萎縮や間質 の線維化, 硬化が認められる. 系球体の大部分には種々 の病変が観察されるが, 同一糸球体においても新旧入り 混じつた病変が認められる（図6). 寸なわち, 手球体 には肉芽腫様変化に陉つているものが多いが，一部には 系球体係蹄とボウマン囊との癒着拉よび半月体形成（回
6) が認められるものもある. また同一系球体にあつて も, 上記の病変の他, 肥厚, 硬化した基底膜をもつ係疃 の局所に新しい細胞の増生が生起している像（図6）や 係蹄中軸部への増生細胞の集積の所見が観察されるもの もむる．電顕的には，中軸部にメザンギウム細胞に類似 した特徵を示す胞体の暗い細胞とそれに接する基底膜様 構造の形成ならびに膠原線維の増殖が観察される.この ような部に接して，そのボウマン襄腔側に存在する毛細 血管腔では，軽度に肥厚した基底膜に沿つて内皮細胞由 来と思われる胞体の明るい細胞の増生が観察される（図 11). 係蹄毛細血管内皮と lamina densa との間にメザ ンギウム細胞に類似した暗い細胞質をもつ細胞の増生 （光影的には肥厚・蛇行を示す基底膜の内皮側に好塩基 性を示す細胞質をもつ細胞の増生が観察された)，基底 膜様構造ならびに膠原線維の形成が観察されるところも ある(図12). 壊死化糸球体が肉芽腫に置換されている ところの電顕的検索では，毛細血管の新生，膠原線維の 増殖を伴つた線維芽細胞の増生がみられ，その間には僅 かに残存する係蹄毛細血管の閉塞像も観察される.ささ に lysosome, phagolysosome を有する大食細胞も認めら れる（図13），尿細管主部上皮は萎縮しており，間質に は線維芽細胞の増生や膠原線維の増殖が著明であり（図 $7 ， 14 ， 15)$ ，これらの一部は蹯開さらに断裂を示す尿 細管上皮下基底膜と萎縮した尿細管主部上皮との間に侵 入していくように見える.

d. 蛋白尿出現後87日一第 2 回抗 腎 血 清 注 射後 67 日 (第 3 回生検)

布腎：肉眼的には前回生検時とほぼ闰様の所見であつ 
た. 組織学的には糸球体の線維化や肉芽腫形成に上るそ の置換がところどころに散見される（図 8)。 また，こ のような変化のみられない系球体では，糸球体係蹄基底 膜の硬化, 中軸部における軽度の細胞の增加, 礎質の增 加や線維（電顕的観察では膠原線維）の形成が認められ る. また，中輔部にそのような変化がみられる係蹄の周 辺側に毛細血管腔が不規則に配置されている像が認めら れるところもあるが，その内腔は赤血球に乏しい，さら に闹一系球体にあつても，血行静止ない儿壊死に陥つた 係蹄のほか，ボウマン䆏壁との癒着を示す係蹄が見い出 されたり，半月体を伴つているところもある.

尿細管組織には，主部上皮の著しい萎縮とその部の上: 皮下基底膜の踈開，蛇行，二重像などが観察される（図 8).上記の変化は電顕的にも明瞭に認められる。この ような部の間質には線維細胞の増生が示されるところが 少なくない。細動脈では中膜平滑筇線維の核周囲の淡明 化が著明に見られる（図8).

e. 蛋白尿出現後199日一第 2 回抗腎血清注 射後179日 （剖検）

右腎：肉眼的に切除症痕巣を除いては，その表面は平 滑で, 割面でも特に異常を認めなからた（重量 $18.0 \mathrm{~g}$ ). 組織学的には腎の約 4 分の 1 の采球体に，係蹄中軸部へ の增生細胞の集積や線維の增殖が軽度に，一部には係蹄 とボウマン霊壁との瘾着が 観察される，尿細管組織で は, 一部に主部上:皮の萎縮や間質の硬化も認められる が，その他ではこのような所見はなく，むしろ肥大の像 が軽度ながらみとめられる. 腎内血管系とくに細動脈に は著明な変化を認めない。

左腎：肉眼的には線維膜の肥厚が著明であつたが，そ の剝離は生検後の瘢痕巣以外では容易で，腎実質表面は 平滑であつた（重量 $5.0 \mathrm{~g}$ )。組織学的には，ほとんぞの 系球体に病変が認められる. 寸なわち, 系球体は線維化 や硝子化を示し，残存系球体にも係嗳の壊死化と肉芽腫 形成の像が認められる。このような糸球体に連らなるボ ウマン囊の基底膜は多くの場合以前の位置に認められる が，多重像を示したり強い蛇行肥厚を示したりしてい る. しかし，壊死化系球体とそれをとりまく肉芽腫局所

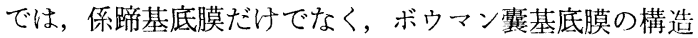
もほとんどうかがうことができない．

一方，尿細管組織についてみると，尿細管主部上皮の 萎縮は著しく，それとともに上皮下基底膜の肥厚や間質 の硬化も著明である. 細動脈では, 内皮細胞の軽度の腫 大, 増生や中膜平滑笳線維の核周囲の淡明化がみられる
が，内膜や中膜の著明な肥厚は観察されない。

\section{総括的観察ならびに考按}

Sarre \& Wirtz (1939) ${ }^{9}$ はウサギの一側腎動脈を結紮 すると同時に，抗ウサギ腎ニワトリ血清をその耳静脈内 に注射し，15分後にその結紮を解くことにより，非結杽 側の腎にのみ糸球体腎炎の発生を見ることを明らかにし た。菅井 $(1957)^{10)}$ はウサギの一側性馬杉腎炎について, 両側腎生検の反復により，96日間の観察の限りでは，反 対側に馬杉腎炎の発生を見ることがなからたということ を明らかにした。

また，長沢 $(1961)^{12)}$ も165日間にわたる観察で一腎生 検による経時的追究はなされていないが一同様の結果を 得ている.さらに, 椎名 (1959) ${ }^{11)}$ は一側腎動脈結禁の もとに，抗ウサギ腎アヒル血清を注射することを反復し て, 西急性系球体腎炎ないし続発性萎縮腎を含む一側性 反復性馬杉腎炎を作成したが，その際反対側の腎には晕 状から軽微な系球体腎炎の発牛が認められるにとどまつ たことを報告している.

著者も，この椎名の方法に従つて，抗ウサギ腎ニワト リ血清の注射を反復することにより，一側性反復性馬杉 腎炎の作成を試みた。

抗腎血清注射後の蛋白尿は初回抗腎血清注射後 $5 \sim 7$ 日で出現し，多くの動物ではその後蛋白尿の程度は減じ て行き17〜23日で消失した。 しかし，ウサギ No. 5，6， 9，10では蛋白尿は程度の差はあつたが 消失することは なかつた．第 2 回の抗腎血清注射後，3〜8 日を経て蛋 白尿は再度出現あるいは増強を示し，その後剖検時まで 持続した. この著者の得た所見は，初回注射後のものに ついては馬杉ら $(1932,1934)^{2) 4)}$, 藤本 $(1954,1955)$ 5) 7), 菅井 $(1957)^{10)}$, 椎名 $(1959)^{11)}$, 長沢 $(1961)^{12)}$ の成績と大差なく，また第 2 回の注射後のそれについて も椎名 $(1959)^{11)}$ の報告と大同小異のものであつた.

一方，結紮を受けなかつた側の腎に広汎な反復性再発 性の糸球体腎炎を発生させることができたが，結禁側の 堅では，少数例に打いてのみ抗腎血清の第 2 回の注射に よる軽度から巣状の糸球体腎炎の発生をみたが，その他 の動物には系球体腎炎の発生はなく, 軽度ながらネフロ ンの代償性肥大の傾向が示されていた。

さて，抗腎血清の初回注射にもとづいて，系球体係蹄 基底膜およびメザンギウムの浮腫性膨化，内皮細胞に主 とし、て由来する係蹄固有細胞の増生，偽好酸球の毛細血 管内への集積, 類線維素血栓などが采球体に観察され, 血行静止による係蹜壊死とそれに続く肉芽腫形成（一 
部), 系球体係蹄とボウマン囊壁との癒着, 半月体形成な どもみられた。 また，係蹄に増生した細胞に沿つて線維 を思わせる成分の形成が認められたが，それは電影的に は基底膜様構造ないし膠原線維の形成によることが明ら かにされた．初回注射後 1 週間の尿細管主部上皮には， その性状が良好で硝子滴变性を示すものも一部に認めた が，注射後 1 箇月近く経過すると主部上皮が菲薄化し， 管腔はすこし拡張し，間質が浮腫性に肥厚するところ もみられた. 電顕的に, 主部上皮の細胞質内に多数の lysosome がみられ, mitochondria は減少し, 基底部細 胞膜嵌入の消失が観察され，上皮下基底膜は疎開・蛇行 していた.

藤本 $(1954)^{5)}$, 藤本ら $(1955)^{6) 7}$ は)サギに抗腎アヒ ル血清を一回注射することにより発生した馬杉腎炎につ いて，腎生検の反復により，系球体係蹄構造の保持・破 壊の程度に基づいて, 系球体係蹄の浮腫性膨化と硬化, 係蹄の網胞構造化と線維化, 係蹄の壊死とその後の肉芽 腫形成といら三種類の糸球体炎病理過程などを明らかに したが，抗ウサギ腎ニワトリ血清を用いた著者の実験に 打いても，その所見を打拉む禅かめることができた。

第 2 回の抗腎血清の静注後の組織所見として, 系球体 炎を免れていた糸球体係蹱に新しい炎症過程が発生した り，硬化・肥厚した基底膜をもつ系球体係蹄に新しく局 所の固着細胞の増生が生起したということを確かめるこ とができた。 また，第 1 回注射により発生した糸球体炎 に伴つて形成された半月体が 既に線維化に陥つていた が，その汪かにいまだ上皮の性格を強く示す新しい半月 体が第 2 回の注射以後に発生したといらことも知ること ができた. 光顕的観察では, 肥厚した基底膜の内皮側に 好塩基性細胞質を示す細胞が認められ，このような部を 電顕にて観察すると, 系球体俰啼の内皮と lamina densa との間に固着細胞が増生しこれらの細胞間に lamina dense と連なる 基底膜様構造や膠原線維が形成されて いる所見が観察された。これは，ヒトの糸球体腎炎など について Arakawa \& Kimmelstiel (1969) ${ }^{13)}$ が記載した “Circumferential mesangial interposition” の所見に匹敵 する変化と解釈される．また，肥厚・二重化した係蹄基 底膜の内側に接して, 細胞内小器官が少なく, 胞体が明 るくみえる内皮由来細胞の增生がみられるところも山つ た. そして，このような係蹄に隣接する係蹄には，細胞 内小器官は少ないが, やや胞体の暗い増生細胞がみら れ，その増生細胞間には基底膜様構造や膠原線維の形成 が観察されるところもあつた。 また，尿細管組織では主
部上皮が次第に萎縮におらいり，この部の上皮下基底膜 の内外飞は線維芽細胞・線維細胞の増生や線維成分の増 殖が認められるという所見が注目された。間質の毛細血 管には赤血球がやや少ない上らに思われた。 また，細動 脈では中膜平滑筋線維の核周囲淡明化の像がみられた.

さらに発病後の経過が長期にわたるとともに，系球体 の線維化・硝子化，尿細管組織の萎縮・硬化の過程があ らわとなることを知ることができた。

糸球体炎の再発像については, Bell $(1950)^{14)}$ が慢性 系球体腎炎の急性増悪の所見として, 残存糸球体に打け る新しい采球体炎の発生, 新しい半月体の形成, 西るい は輸入細動脈に和ける血栓形成等を記載している. 椎名 $(1959)^{11)}$ は抗腎血清の 2 回目の注射によるウサギ馬杉 腎炎に打注再発像として, 残存系球体における新しい 糸球体炎の発生ならびに新しい半月体の形成および軽度 采球体炎の後に壁が硬化した係蹄に括ける新しい炎症 （細胞増生による網胞構造化の過程）の加重を観察した と報告している．著者も椎名 $(1959)^{11)}$ の報告とほぼ同 様の結果を得たが，それをさらに電䫓的検索によつて確 かめることができた．係蹄中軸部への増生細胞の集積と 增生細胞間の基底膜様構造・膠原線維の形成拉よび周辺 毛細血管腔に抢ける新しい細胞増生の所見, 同一係蹄に 相接して新旧の糸球体炎の像が観察されること, 基底膜 の肥厚・二重化像を呈する毛細血管脭に新しい細胞増生 （主に内皮由来）が認めら机ることなどがそれである.

次注, この上らな糸球体炎の反復, 再発, 系球体の荒 廃に伴う尿細管組織の態度について論じることとする.

尿細管については以前より糸球体依存性が強いといら ことが指摘されてきているが(15)16)，系球体腎炎ことに慢 性腎炎や続発性萎縮腎に预ける尿細管上皮・基底膜・間 質の変化についての電顕的検索をも含む詳細な研究は少 なく，また上皮や間質の態度についての，これらの場合 と腎硬化症の際との異同についても，ほとんど明らかに されていないといわざるを得ない現状である.

著者の実験では，抗腎血清の初回注射後約 1 箇月たつ と, 傷害の強い糸球体に所属与る尿細管主部上皮は菲薄 化し, 上皮下基底膜との間に少量の線維成分の存在が認 められ，基底膜は疎開・肥厚・蛇行ならびに二重像など を示すようになつた。これに接する間質は浮腫を示した が，毛細血管腔は一般によく開存しており，そこに赤血 球もかなり認められたが，一部には血桼停滞が示されて いるところもあつた.

抗腎血清の第 2 回注射後には, 菲薄化していた尿細管 
主部上皮は次第に萎縮におちいり，尿細管上皮下基底膜 との間に，さらに線維芽細胞の出現や線維成分の増殖が 目立つようになつた。周囲の毛細血管腔は不充分ながら 開存していたが，そこには赤血球数が少なくなつてい た.

慢性系球体腎炎や続発性萎縮腎に招ける尿細管主部上: 皮の萎縮については，従来，系球体の荒廃に基づく尿細 管組織への潅流の低下がその原因をなするのという理解 が広く行なわれて来た ${ }^{15) 16)}$ ．乙かし，著者の実験で明ら かにされた尿細管主部組織の萎縮と硬化の過程は, 糸球 体構造の改築に続く局所の線維化・硝子化，糸球体壊死 後の肉芽腫形成などに陥つた糸球体に関連して発生して いたといらことが注目される，すなわち，その発生と進 行にあたり糸球体機能の著しい低下ないしその廃絶に伴 万所属尿細管組織の無為萎縮と解釈される過程の役割が 強く示唆されるところである，ただ，この種の変化の進 行したと思われる部位では尿細管組織の間質毛細血管腔 の狭小化や赤血球数の減少が観察され，病変の進行に伴 ら二次的な局所の血行の低下が特こり，それがまた上皮 の萎縮をさらに増強することとなつたという可能性をも 否定するわけにはいかない。

細動脈の中膜平滑筋線維の核周囲の淡明化が実験期間 の長期化に伴つて患側腎に観察されたが，このような細 動脈壁の変化が糸球体の荒廃や所属尿細管主部組織の萎 縮・硬化が進行した領域に比較的目立つように思われ た。 その発生にあたり糸球体毛細血管の閉塞にもとづく 末梢抵抗の増大の役割が重視されるとともに尿細管主部 上皮の強い萎縮に伴う局所への潅流の必要性の低下が因をなした可能性も推察されるところである.

著者の実験では，患側腎に糸球体腎炎の反復，再発に よる腎組織の荒廃の過程が見られたが，対側腎には軽度 ながらネフロンの代償性肥大の傾向がうかがわれた。 ま た，患側腎の内部にネフロンの代償性肥大といらべき像 はほとんど見い出されなからたが，それは患側腎の傷害 にもとづく対側腎の肥大により，腎機能の低下がある程 度代償されていたためと思われる。しかし，それととも に糸球体腎炎の反復によつて，患側腎には肥大を拈こし らるよらなネフロンがほとんど残されていなかつたとい ら事実も見逃すわけにはいかない。

以上のように，著者の実験では一側腎の機能がほぼ正 常に保たれるので，患側腎に尿毒症による変化を引き特 こすことなく，組織学的に進行した糸球体腎炎を発生さ せる事が可能であつたが，この方法をさらに駆使するこ
とにより一層徹底した病変の作成も可能と思われるし， また，健側腎の切除といら方法を加えることにより腎機 能面での負担が系球体腎炎に及ぼす影響などについても 観察しうるものと思われる.

\section{結 語}

著者は，糸球体腎炎の反復による形態学的変化を追求 するために，ウサギの一側腎動脈の20分間の結紮中に， 抗ウサギ腎ニワトリ血清を耳静脈内に注射することを反 復することにより，一側性反復性馬杉腎炎を作成し腎生 検の反復扣よび剖検により経時的に得られた材料につい て，電子顕微鏡的検索を妇含む組織病理学的研究を行な つた. その観察期間は最長発病後199日に括よんだ.

1. 1 回の抗ウサギ腎ニワトリ血清注射に上る馬杉腎 炎の一側性発生を確かめるとともに，その反復に際して もこの特徵が法とんど失なわれないことを知り得た。患 側腎は経過とともに，しだいに縮小する傾向を示したの に反し，対側腎には肥大するといら特徵がうかがわれ た.

2. 新旧の糸球体炎像ならびに新しい执よび線維化に 陥つた半月体の混在の他，肥厚・硬化した基底膜をもつ 系球体係蹄に発生した細胞増生などは馬杉腎炎の反復性 発生ないし再発の像と解釈される。 その他, 糸球体ない 乙その係蹄の壊死後の肉芽腫形成の像もみられた。倸蹄 の周辺毛細血管壁に抢ける，いわゆる circumferential mesangial interposition に相当する变化の発生. 観察さ れた。

3. 保蹄構造の改築ないし破壊の著しい系球体に所属 する尿細管組織，とくに主部の上皮はしだいに萎縮に陥 る一方，尿細管上皮下基底膜の二重像，疎開，蛇行なぞ の所見が観察され，間質は浮腫に続いて硬化へと進行す ることが示された，基底膜上皮側に和ける線維芽細胞や 線維成分の出現も注目された。 これらの変化のヘンンの 係蹄への波及の傾向も示された.

4. 傷害の強い糸球体局所を潅流寸る細動脈には，中 膜平滑筋線維の核周囲の淡明化が認められるものも㐫つ ז.

本研究の遂行および論文の作成に岕てり，御指導と御 校閲を頂いた藤本輝夫教授（病理学第一教室）およびこ の研究の過程で，御鞭達を頂いた前川正信教授（泌尿器 科学教室）飞深謝致します。ささらに、多大なる御協力を 頂いた中西純造博士（現市立豊中病院泌尿器科部長）, 病 理学第一教室・皮虚科学教室・内科学第一教室・中央臨 床検查部諸兄姉に心から御礼を申し上げます。とくに電 
子顕微鏡的検索の技術面で御教示いただいた石井正光助

手（皮膚科学教室）ならびに岩本勉氏（電子顕微鏡研究

室）に束心より感謝致します。

（本論文の要旨は第 202回大阪市医学会例会, 第68回 日本泌尿器科学会総会, 第69回日本病理学会総会飞て発 表した。また。この研究の遂行にあたり文部省科学研究 費一昭和54年度一般研究 B, 課題番号 448137, 研究代表 者藤本輝夫一の補助を得心ことに感謝する。）

\section{文献}

1) 馬杉復三, 富塚八十一：抗臟器血清による臟器 の特異性変化の本態飞就て, 特に Nephrotoxin 及び Hepatotoxin に上る腎及び肝の変化に就 て。（附）系球体腎炎及び子簿肝の病理発生に 就 て。千葉医会誌, 9 (第 1 部), 1142-1175, 1931.

2）馬杉復三，佐藤保雄, 村沢貞雄, 富塚八十一： 抗腎血清による実験的系球体腎炎に就て。千葉 医会誌, 10 (第 1 部), 787-801， 1932.

3) Masugi, M.: Über das Wesen der spezifischen Veränderungen der Niere und der Leber durch das Nephrotoxin bzw. das Hepatotoxin. Zugleich ein Beitrag zur Pathogenese der Glomerulonephritis und der eklamptschen Lebererkrankung. Beitr. path. Anat., 91, 82$112,1933$.

4) Masugi, M.: Über die experimentelle Glomerulonephritis durch das spezifische Antinierenserum. Ein Beitrag zur Pathogenese der diffusen Glomerulonephritis. Beitr. path. Anat., 92, 429-466, 1934.

5) Fujimoto, T.: Histopathologic study of Masugi nephritis. The mode of devclopment of the glomerular changes. Acta Path. Jap., 4, 1-19, 1954.

6) Fujimoto, T. and Akashi, S.: Mode of development of edematous-sclerosing processes in glomeruli. Histopathologic study of Masugi nephritis. Osaka City Med. J., 2, 7-20, 1955.
7) Fujimoto, T. and Yamanaka, H.: Mode of development of the necrotizing processes in glomeruli. Histopathologic study of Masugi nephritis. Osaka City Med. J., 2, 21-31, 1955.

8) Fujimoto, T., Okada, M., Kondo, Y. and Tada, T.: The nature of Masugi nephritis. Histo- and immunopathological studies. Acta Path. Jap., 14, 275-310, 1964.

9) Sarre, H. und Wirtz, H.: Geschwindigkeit und Ort der "Nephrotoxin"-bindung bei der experimentellen Glomerulonephritis. Klin. Wschr., 18, 1548-1550, 1939.

10）菅井道雄：一側性 馬杉腎炎の組織病理学的研 究. 日病会誌, 46, 722-737, 1957.

11）椎名岩松：ウサギにおける一㑡腎動脈結槂法を 用いた反復馬祄督炎の組織病理学的研究.千葉 医会誌，35，739-755，1959.

12）長沢俊彦：実験的慢性腎炎。日腎誌，3，193209, 1961.

13) Arakawa, M. and Kimmelstiel, P.: Circumferential mesangial interposition. Lab. Invest., 21, 276-284, 1969.

14) Bell, E.T.: Glomerulonephritis. In: Renal diseases. 2nd ed., p. 146-265, Lea \& Febiger, Philadelphia, 1950.

15) Beregi, E. and Varga, I.: Structure of the normal kidney in man. In: Renal biopsy in glomerular disease. Clinical, histological, immunohistological and electron-microscopic studies., p. 46-65, Akadémiai Kiadó, Budapest, 1978.

16) Heptinstall, R.H.: Chronic glomerulonephritis, end-stage kidney, and visceral changes in chronic renal failure. In: Pathology of the kidney (edited by Heptinstall, R.H.). 2nd ed., Vol. I, p. 469-495, Little, Brown and Co., Boston, 1974.

（1980年11月 6 日受付, 特別掲載） 


\section{附図説 明}

図 1 增生性系球体炎と，血栓形成・血行静止のみられる系球体炎。PAS 染色。サギNo.5.第 1 回抗荋血 清注射後30日。第 2 回生検。

図 2 系球体係蹄をまきこんだ肉芽腫形成ＨE 染色。ウサギNo. 5。第 1 回抗腎血清注射後 30 日。第 2 回生 検.

図 3 係蹄中軸部の線維化を伴つた増生細胞の集積, 周辺側には血腔が認められる。PAS 染色。ウサギNo.

5 . 第 2 回抗腎血清注射後 34 日。剖検.

図 4 基底膜の硬化を示す系球体係蹄に括ける新しい細胞增生, 基底膜の二重像が目立ち，一部には“Circum-

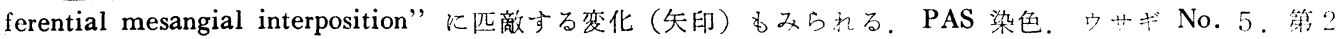
回抗腎血清注射後34日。剖検。

図 5 係蹄中軸部への細胞集積, 線維化と周辺血管腔内への新しい細胞增生. HE 染色. ウサ平 No. 10. 符 2 回抗腎血清注射後 13 日。第 2 回生検.

図 6 糸球体の細胞增生後の線維化, 硬化した基底膜をもつ係蹄におこつた細胞增生の強い系球体炎お上び拈 月体形成，HE 染色．ウサギNo. 9. 第 2 回抗腎血清注射後38日。第 2 回生検.

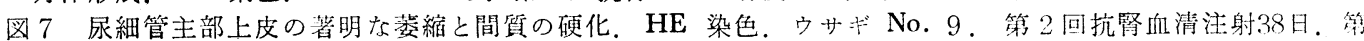
2 回生検。

図 8 增生性系球体炎後の線維化とその周囲の肉芽腫性反応, 所属尿細管主部上皮の強い茨繀と間質の硬化, 中膜平滑筋線維の核周囲の淡明化. HE 染色. ウサギ No. 9 . 第 2 回抗腎血清注射後 67 日. 第 3 回生検.

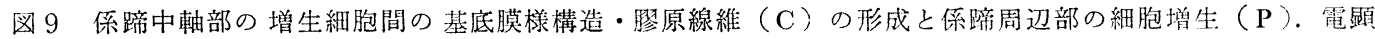
像。ウサギ No. 5 。第 2 回抗腎血清注射後34日。剖検。

図10 增生細胞の強拓大像。その胞体は明るく細胞内小器官も少ない。增生細胞の中に怯 lamina densa の内 側を直接被輹するものがみられる。電影像。ウサギ No. 10. 第 2 回抗腎血清注射後 13 日。第 2 回生検。

図11 係蹄中軸部（A）への増生細胞の集積と增生細胞間の基底膜㥞構造・賿原線維の形成抢よび周辺毛細组 管腔にお汀る新しい細胞増生 (P). 電顕像。ウサギ No. 9. 第 2 回抗腎血清注射後38日。第 2 回生検。

図12 係踹毛細血管内皮々 lamina densa との間に細胞增生，基底膜㥞構造・膠原線維（C）の形成がみら和

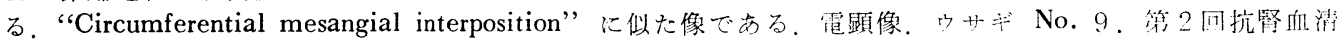
注射後38日。第 2 回生検.

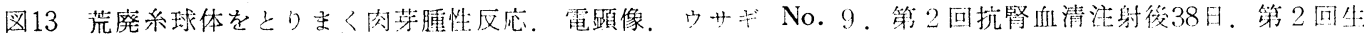
検.

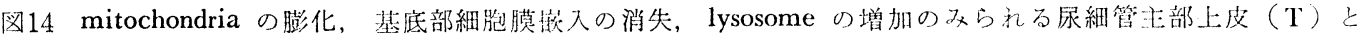

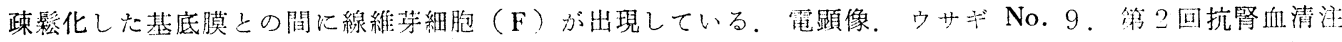
射後38日。第 2 回生検。

図15 著しく萎縮した尿細管主部上皮（ $\mathrm{T} ）$ の周囲に線維芽細胞（F）や形質細胞がみられる。また，苳縮し た上皮と基底膜との間が著しく開大しているところ（）もある。電顕像。ウサギ No.9. 第2 2 回抗腎血 清注射後38日。第 2 回生検。 


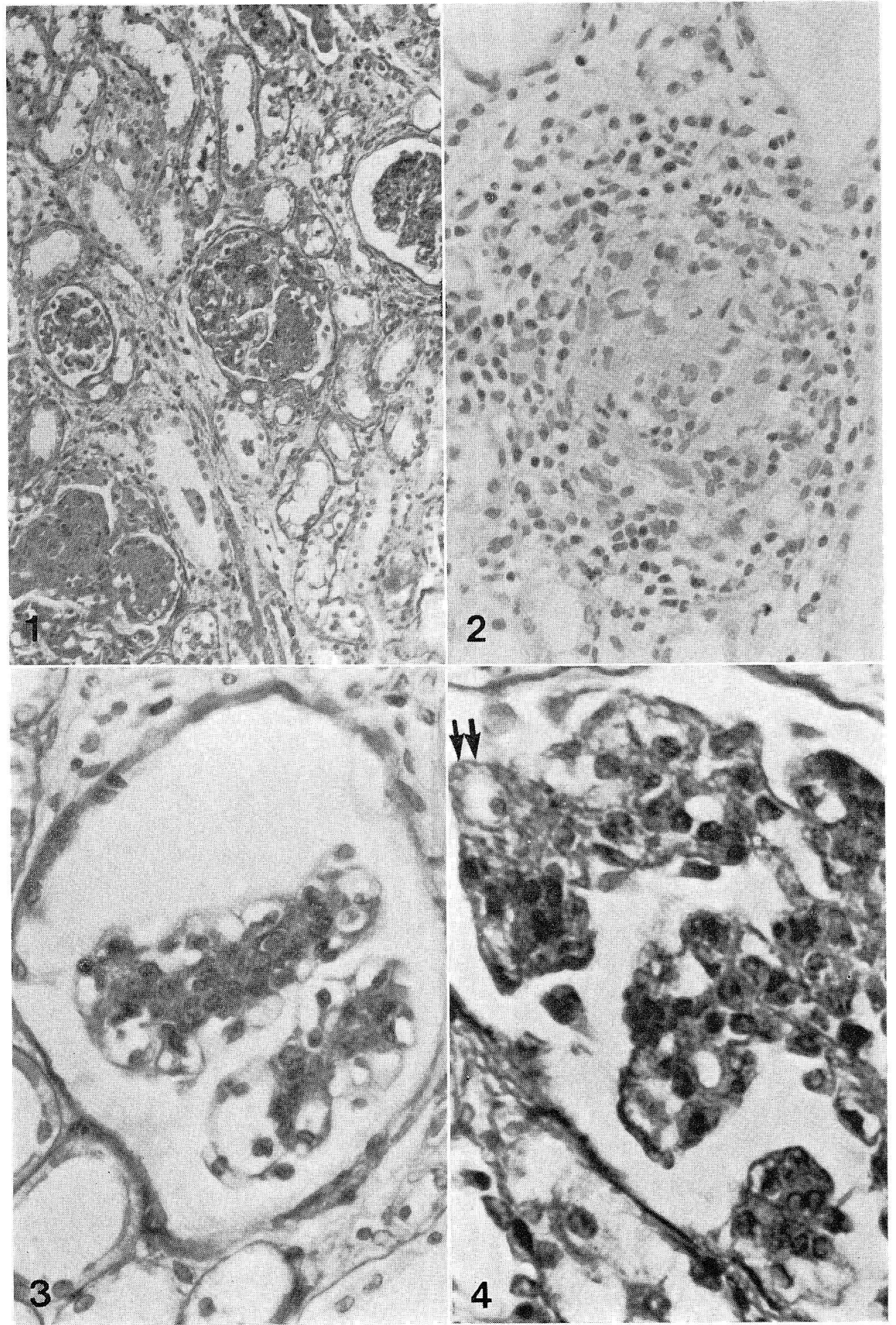




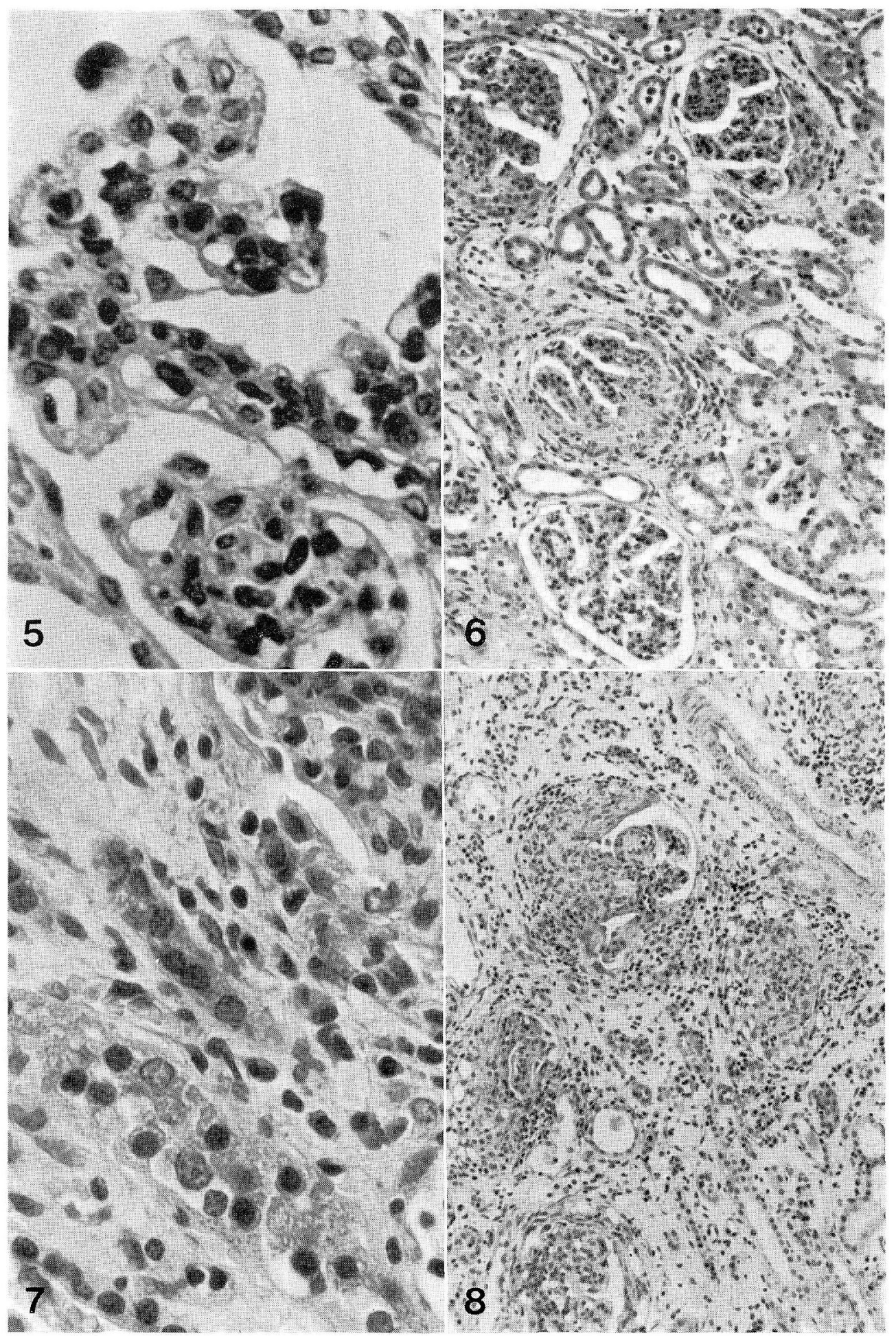




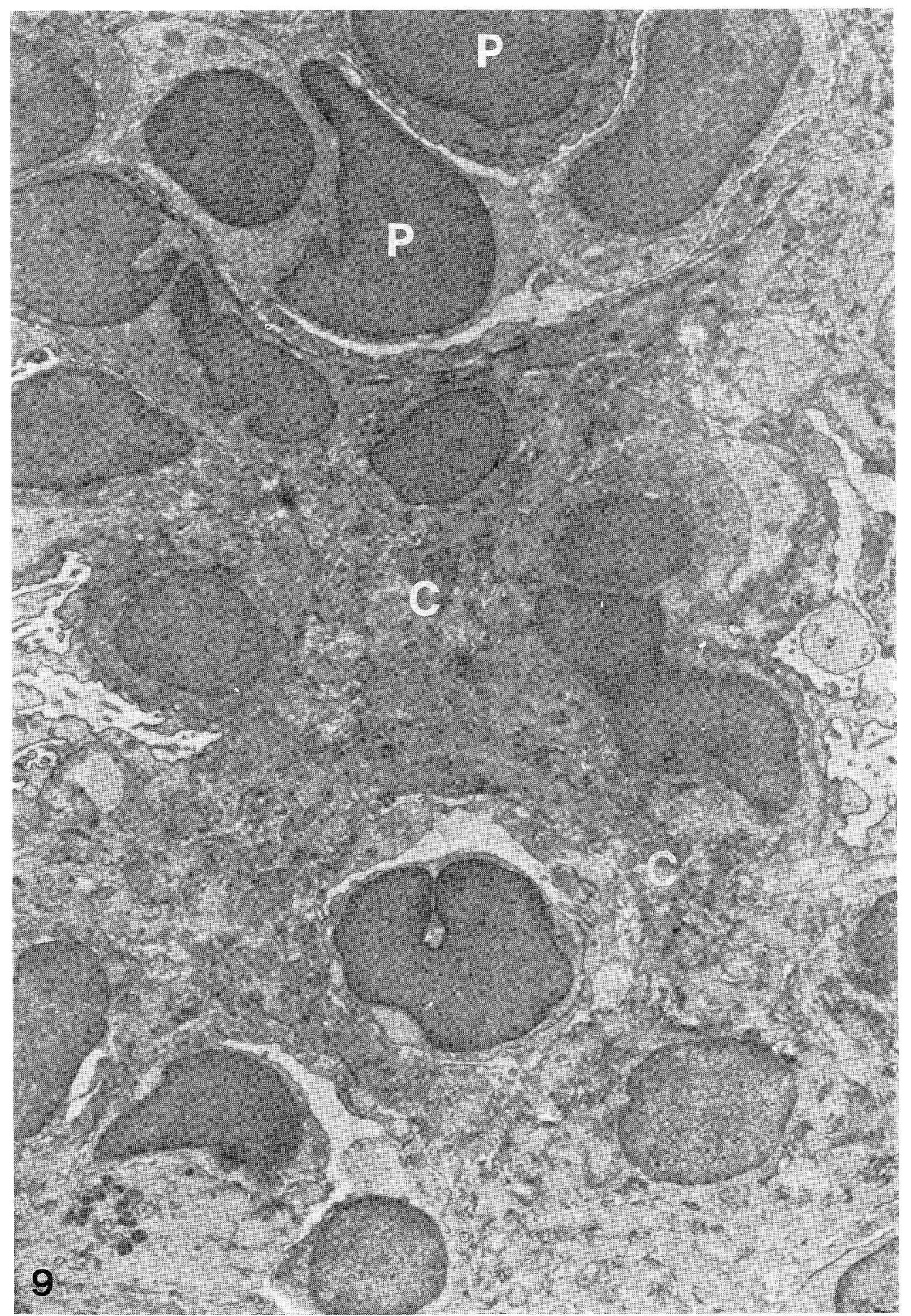




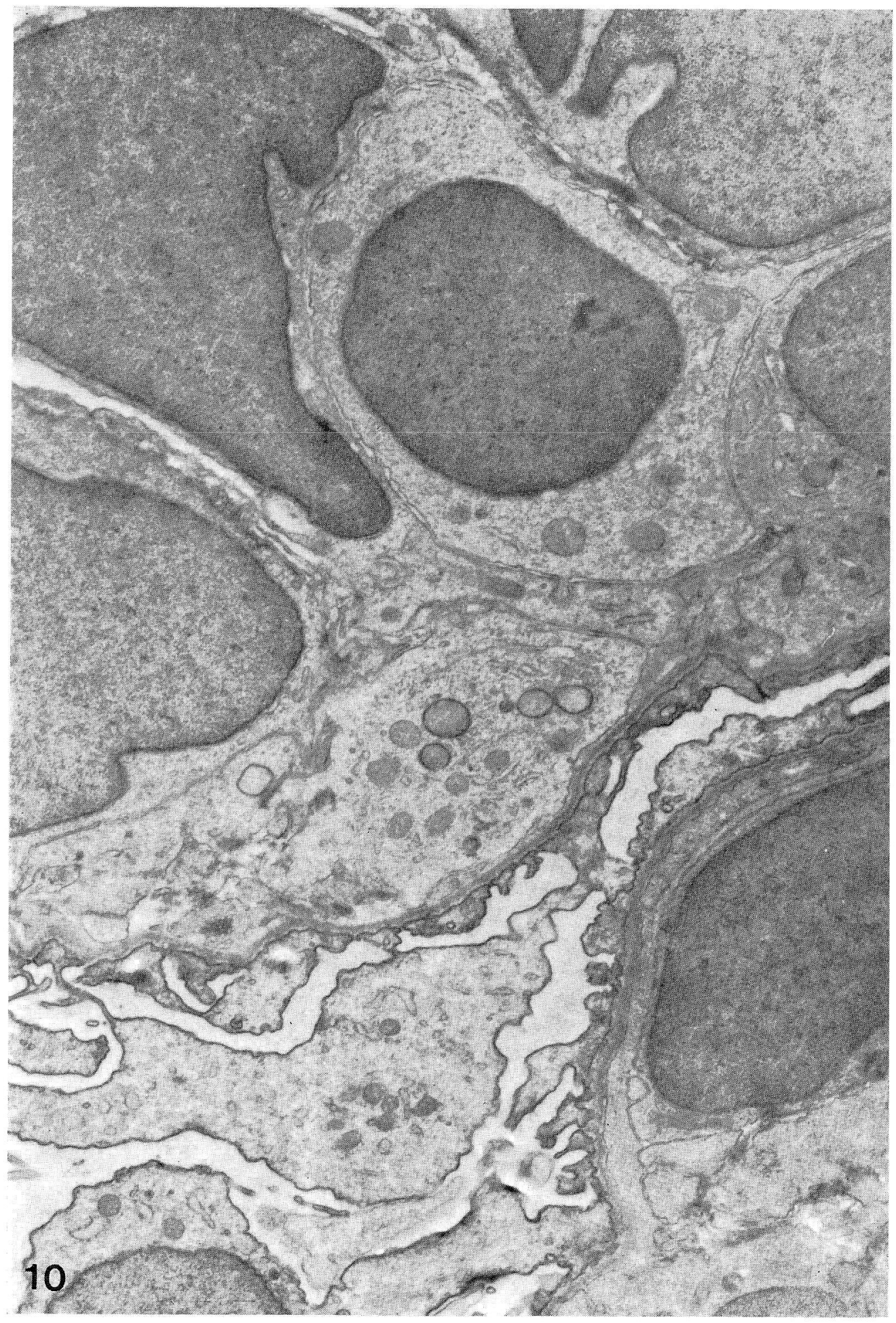




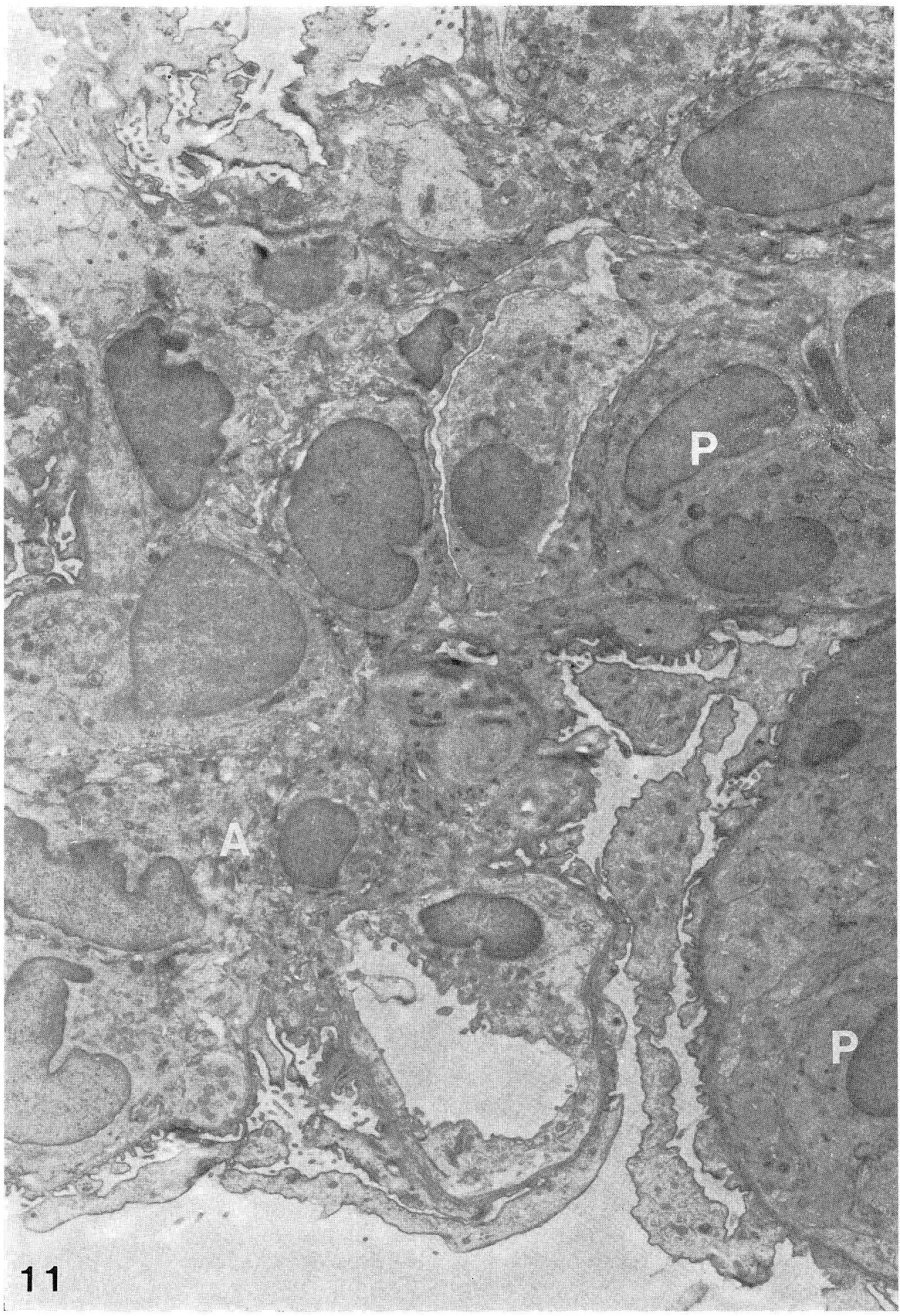




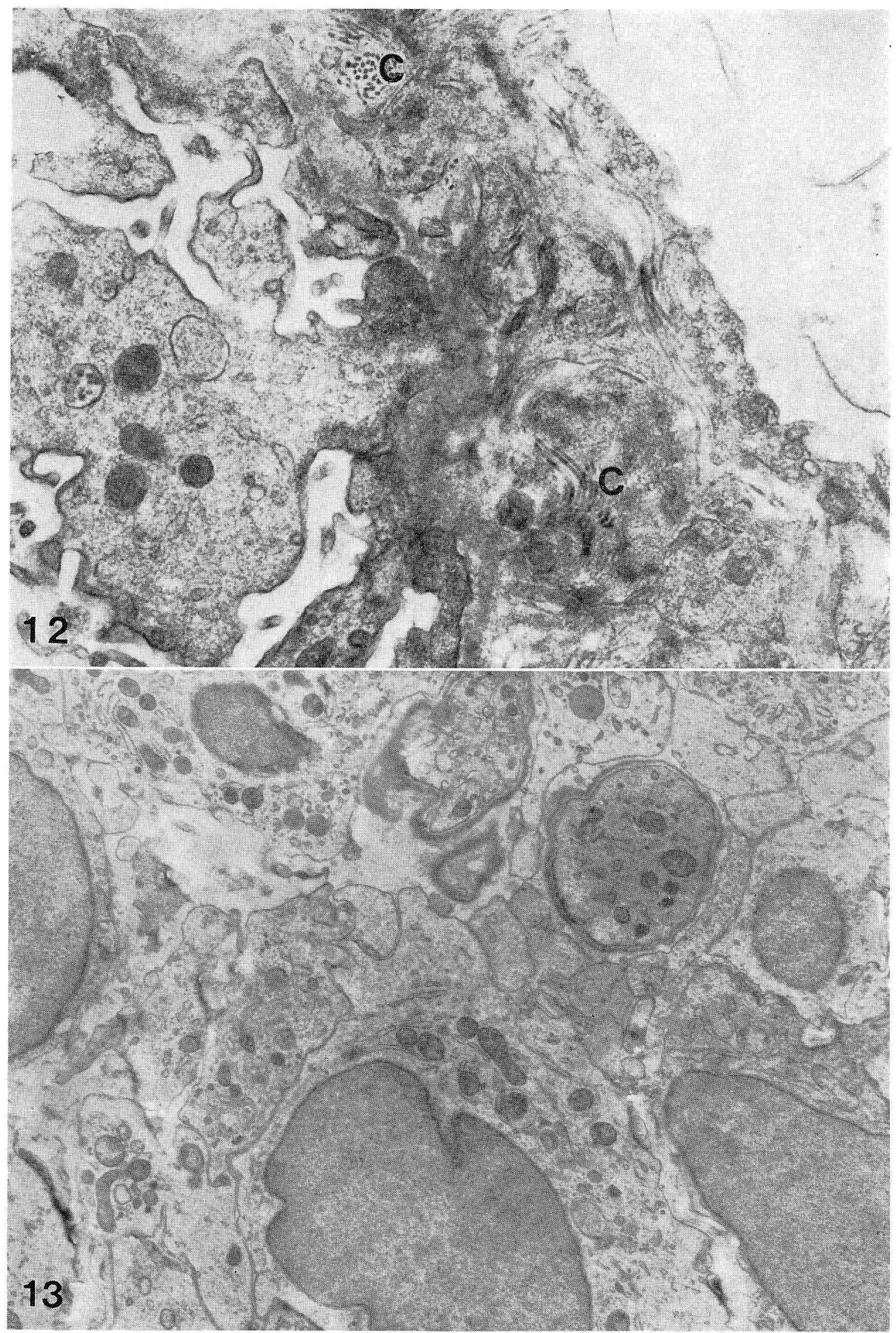




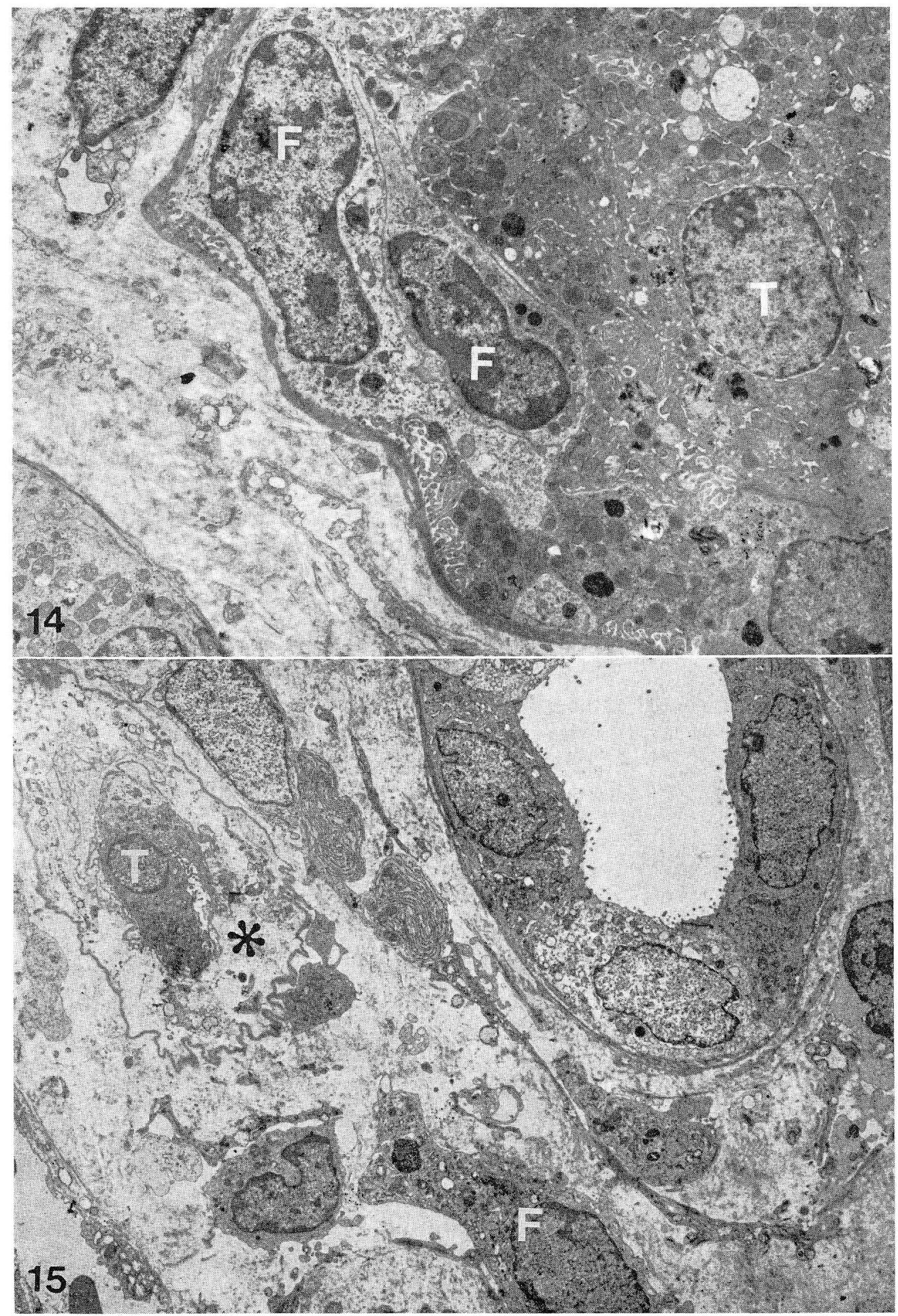

